\title{
The Effect of Digital Marketing and Media Promotion Utilization to a Bakpia Patok Yogyakarta SMES' Sales Performance
}

\author{
Marissa Grace Haque \\ STIE Indonesia Banking School, Jakarta, Indonesia \\ Email: marissa.haque@ibs.ac.id
}

(Received: December 12-2019; revised: April 15-2020; published: June 31-2020)

\begin{abstract}
This study aims to determine the effect of digital marketing and the use of media promotion on its sales performance of one of Bakpia Patok SMEs in Yogyakarta. The method used is explanatory research, and statistical analysis with regression test, correlation, determination, and hypothesis test. Results of this digital marketing study has a significant effect on sales performance 41,8 percent, Hypothesis testing is obtained by $t$ arithmetic $>t$ table or $(8,208>1,986)$. The use of promotional media has a significant effect on sales performance 43,2 percent, Hypothesis testing is obtained by $t$ arithmetic $>t$ table or $(8,457>$ 1,986). Digital marketing and the use of promotional media simultaneously have a significant effect on sales performance with the regression equation $\mathrm{Y}=9,672+0,362 \mathrm{X} 1+0,405 \mathrm{X} 2$ and contribute with as much influence as 52,4 percent, Hypothesis testing is obtained by F-count > F table or $(51,264>2,700)$.
\end{abstract}

Keywords: digital marketing; media promotion utilization; sales performance

\section{INTRODUCTION}

Yogyakarta is famous with Gudeg and Bakpia Patok culinary. But when it comes to consume Gudeg tourists need to have more adjustment of its taste, with Bakpia Patok tourists can much easier adopt with its taste due to its similar 'sense' with some other cookies from around the world.

Culinary assets also will raise the national dignity which will cause a positive impact on the national economy (Harisudin, 2011). Traditional culinary is one of the national assets, if it can be developed to the fullest by its management. Bakpia Patok is one of the very famous traditional culinary from Yogyakarta. Along with the increase of domestic and international tourist numbers who come to Yogyakarta, certainly SMEs which are producing Bakpia Patok contribute a vast impact on its emergence of Yogyakarta food industry (Saputra \& Rindrasih, 2012).

The Bakpia Patok industries in Yogyakarta which is now well growing, and its growing is in line with the growing of IT and ICT which are now also very broad and vast. Yet, IT and ICT are what so called as the Internet of Things or I.o.T, as well as the apps developments. To run their business, various SMEs activities have taken advantage of it. Numbers of rising competitors are some other considerations for them to face its tight competition. Appropriate marketing and media strategies are used to be able to reach the market target in order to gain more profits.

Digital Marketing is only one of marketing media tools which currently is widely used to support SMEs various marketing activities (Bautista, 2020; Gamache, 2019; Hendrawan, 2019; 
234|Jurnal Ilmiah Ilmu Administrasi Publik: Jurnal Pemikiran dan Penelitian Administrasi Publik

Volume 10 Number 1, January - June 2020. Page 233-243

Kriechbaumer, 2014; Matopoulos, 2012; Miersch, 2018; Mitroulis, 2019). Due to its development, many SMEs gradually abandon the traditional marketing model, and switch it to a more modern digital marketing way (Farida et al., 2017; Jasmani \& Sunarsi, 2020; Purwanti et al.,, 2020; Rengifurwarin et al., 2018). Its new approach gives a more advanced communications manner as well as transactions, where real time can be delivered at any time and at any place, globally. The more choices of food products sold in the market, the better diverse choices of them for consumers will be. As the consequences of its conditions mentioned above, consumers will be much careful and sharp in responding to every product launched and delivered to the market. In producing products, many companies need to adjust their products to consumers' needs, desires, and tastes, or to fulfill and satisfy their customers' expectations. Furthermore, in order to win its market competition, companies must also pour the market with a wide range of variant products, to satisfy consumers with many alternatives, before they make decisions to buy their products.

Local food industries are now increasing in Yogyakarta, due to many tourists who are coming to Yogyakarta as well as to its demand from the locals. Especially those who are coming to Yoyakarta, it is a must for them whenever they leave Yogyakarta, to bring some 'oleh-oleh' or typical souvenirs of Yogyakarta. And some of them are the typical culinary which are easy to carry and and can be stored for a long time, and nonetheless it is Bakpia Patok. Bakpia Patok has become one of Yogyakarta's most popular foods for tourists when visiting Yogyakarta.

Bakpia Patok made from kneaded flour and filled with cooked green beans. To date, this traditional food has been innovated into several flavors. Not only traditionally contains green beans, but now Bakpia Patok also contains of cheese, chocolate, purple sweet potatoes, and others.

According to the office of Dinas Perdagangan, Perindustrian, dan Koperasi (Disperindakop) Yogyakarta, Bakpia Patok industry in the city of Yogyakarta is a traditional food industry that has the highest business unit as 68 SMEs (Small Medium Enterprises) or UMKM (Usaha Mikro, Kecil, dan Menengah). This is more than other special foods such as Gudeg which consists of 30 SMEs or UMKM (Rengifurwarinet al.,, 2018). With this large number of chat-based social media users (which are increasingly enhanced opportunities for SMEs in their markets) to develop more usage of smartphones (Lucyantoro et al, 2017, in Hendrawan, et al., 2019)

Communicating a brand for products and services, media is needed to reach the intended target audience. This form of communication is called marketing communication. The purpose of this communication is to spread information, influence, educate, entertain, and remind the audience. Integrated marketing communication or IMC activities are inseparable from the existing promotional mix, which are consists of: (1) advertising; (2) personal selling; (3) promotional sales; (4) public relations; and (5) direct marketing. There is one element which is included as an element of the promotional mix mentioned, it is (6) the digital marketing (Aras et al., 2017; Muhammad Araset al., 2018; Foroudi, 2017; Keller and Lane, 2013; RiveraTrigueros, 2019).

For the five elements of the promotional mix, the existence of each variable and lately with the additional one of the digital marketing, support to its management effective and efficiency (Yoga and Nurmahdi, 2018 in Hendrawan 2019). 
Online marketing is much suitable for new types of business beginners. Surely costeffective, because they do not have to hold a place or booth to display goods or services, can be controlled alone without having to recruit employees, unlimited time or work hours, and has a broad market reach, since online marketing is usually supported by the presence of websites or social media such as facebook, instagram, whatsapp, and others.

Advertising is one of promotional tools, and promotions support sales representatives. Advertising begins the process of selling, and then following with the valuable introduction to its prospective customers, before making personal contact with them. Through advertising services, due to less time is needed to inform prospects about the features and benefits of its products, many other aspects such as time, energy, and money can be saved. Particularly, advertising itself is able to legitimize to what is claimed by the seller's representative will seemed more credible. Therefore, promotion is very important, since it helps accelerate the achievement of sales goals to the max. Based on the description above, this study is aimed to elaborate "The Effect of Digital Marketing and Media Promotion Utilization to Bakpia Patok Yogyakarta's Sales Performance."

\section{METHOD}

Populations in this study are 96 respondents from Yogyakarta which are costumers of P.T XYZ's Bakpia Patok productions. The sampling technique in this study is saturated sampling, where all members of the population are sampled. Therefore, the sample in this study are 96 respondents. Type of research used in this study is associative, where the aim is to determine the effect of independent variables on both partial and simultaneous dependent variables. Instrument test used to analyze data are: (1) classical assumption test; (2) regression; (3) coefficient of determination; and (4) hypothesis testing (Creswell and Creswell, 2017).

\section{RESULT AND DISCUSSION}

\section{Descriptive Analysis}

In this test used to determine the minimum and maximum scores, mean score and the standard deviation of each variable. The results are as follows:

\section{Table 1}

Results of Descriptive Statistics Analysis

Descriptive Statistics

\begin{tabular}{l|r|r|r|r|r}
\hline & N & Minimum & Maximum & Mean & Std. Deviation \\
\hline Digital marketing (X1) & 96 & 32 & 48 & 38.44 & 3.803 \\
\hline Use of promotional media (X2) & 96 & 30 & 45 & 38.40 & 3.663 \\
\hline Sales Performance (Y) & 96 & 32 & 46 & 39.13 & 3.555 \\
\hline Valid N (listwise) & 96 & & & & \\
\hline
\end{tabular}


236 Jurnal Ilmiah Ilmu Administrasi Publik: Jurnal Pemikiran dan Penelitian Administrasi Publik

Volume 10 Number 1, January - June 2020. Page 233-243

Digital marketing obtained a minimum variance of 32 and a maximum variance of 48 with a mean score of 3.84 with a standard deviation of 3.803. Utilization of promotional media obtained a minimum variance of 30 and a maximum variance of 45 with a mean score of 3.84 with a standard deviation of 3.663. Sales performance obtained a minimum variance of 32 and a maximum variance of 46 with a mean score of 3.91 with a standard deviation of 3.555 .

\section{Verification Analysis}

This analysis is intended to determine the effect of independent variables on the dependent variable. The test results are as follows:

\section{Multiple Linear Regression Analysis}

This regression test is intended to determine changes in the dependent variable if the independent variable changes. The test results are as follows:

Table 2

Results of Multiple Linear Regression Testing

\begin{tabular}{|c|c|c|c|c|c|}
\hline \multirow[b]{3}{*}{ Model } & \multicolumn{5}{|c|}{ Coefficients ${ }^{\mathrm{a}}$} \\
\hline & \multicolumn{2}{|c|}{$\begin{array}{l}\text { Unstandardized } \\
\text { Coefficients }\end{array}$} & \multirow{2}{*}{$\begin{array}{l}\text { Standardized } \\
\text { Coefficients } \\
\text { Beta }\end{array}$} & \multirow[b]{2}{*}{$\mathrm{t}$} & \multirow[b]{2}{*}{ Sig. } \\
\hline & B & Std. Error & & & \\
\hline 1 (Constant) & 9.672 & 2.920 & & 3.312 & .001 \\
\hline Digital marketing (X1) & .362 & .085 & .387 & 4.247 & .000 \\
\hline Use of promotional media (X2) & .405 & .089 & .417 & 4.571 & .000 \\
\hline
\end{tabular}

a. Dependent Variable: Sales Performance (Y)

Based on the test results in the table above, a regression equation is obtained $\mathrm{Y}=9,672+$ $0,362 \mathrm{X} 1+0,405 \mathrm{X} 2$. From the equation explained as follows: Constants of 9,672 interpreted if digital marketing and the use of promotional media does not exist, then there has been a value of sales performance of 9,672 point.

1) Digital marketing regression coefficient of 0,362 this number is positive, meaning that there is an increase in digital marketing by 0,362 then the sales performance will also increase by 0.362 points;

2) Regression coefficient of promotion media utilization is equal to 0,405 , this number is positive, meaning that there is an increase in the use of sebesa promotion media 0,405 then the sales performance will also increase by 0.405 points.

\section{Correlation Coefficient Analysis}


Correlation coefficient analysis is intended to determine the degree of relationship strength of the independent variables on the dependent variable either partially or simultaneously. The test results are as follows:

Table 3

Test Results of Digital marketing Correlation Coefficient on Sales Performance. Correlations $^{\mathbf{b}}$

\begin{tabular}{llr|r}
\hline & & $\begin{array}{c}\text { Digital marketing } \\
(\mathrm{X} 1)\end{array}$ & \multicolumn{2}{c}{$\begin{array}{c}\text { Sales Performance } \\
\text { (Y) }\end{array}$} \\
\hline Digital marketing (X1) & Pearson Correlation & 1 & $.646^{* *}$ \\
\cline { 2 - 4 } & Sig. (2-tailed) & & .000 \\
\hline Sales Performance (Y) & Pearson Correlation & $.646^{* *}$ & 1 \\
\cline { 2 - 5 } & Sig. (2-tailed) & .000 & \\
\hline
\end{tabular}

**. Correlation is significant at the 0.01 level (2-tailed).

b. Listwise $\mathrm{N}=96$

Based on the test results obtained by the correlation value of 0.64 , means that its digital marketing has a strong relationship to its sales performance.

Table 4

Correlation Coefficient Testing Results Utilization of promotional media on Sales Performance

\begin{tabular}{llr|r} 
& \multicolumn{1}{c}{ Correlations $^{\mathbf{b}}$} & & \\
\hline & & $\begin{array}{c}\text { Use of } \\
\text { promotional } \\
\text { media (X2) }\end{array}$ & \multicolumn{1}{c}{$\begin{array}{c}\text { Sales } \\
\text { Performance } \\
(\text { Y) }\end{array}$} \\
\hline Use of promotional media (X2) & Pearson Correlation & 1 & $.657^{* *}$ \\
\cline { 2 - 5 } & Sig. (2-tailed) & .000 \\
\hline Sales Performance (Y) & Pearson Correlation & $.657^{* *}$ & 1 \\
\cline { 2 - 5 } & Sig. (2-tailed) & .000 & \\
\hline
\end{tabular}

**. Correlation is significant at the 0.01 level (2-tailed).

b. Listwise $\mathrm{N}=96$

Based on the test results obtained a correlation value of 0.657 means that the use of promotional media has a strong relationship to sales performance.

\section{Table 5}

Test Results of Digital marketing Correlation Coefficient and Simultaneous Utilization of promotional media on Sales Performance.

Model Summary

\begin{tabular}{lrrrrr}
\hline Model & R & R Square & Adjusted R Square & Std. Error of the Estimate \\
\hline 1 & $.724^{\mathrm{a}}$ & .524 & .514 & 2.478 \\
\hline
\end{tabular}


238 Jurnal Ilmiah Ilmu Administrasi Publik: Jurnal Pemikiran dan Penelitian Administrasi Publik Volume 10 Number 1, January - June 2020. Page 233-243

a. Predictors: (Constant), Use of promotional media (X2), Digital marketing (X1)

Based on the test results obtained a correlation value of 0.742 means that digital marketing and the use of promotional media, simultaneously have a strong relationship to sales performance.

\section{Analysis of the Coefficient of Determination}

Analysis of the coefficient of determination is intended to determine the percentage of influence of the independent variable on the dependent variable either partially or simultaneously. The test results are as follows:

Table 6

Test Results of Digital marketing Determination Coefficient on Sales Performance.

Model Summary

\begin{tabular}{lr|r|r|r}
\hline Model & R & R Square & Adjusted R Square & Std. Error of the Estimate \\
\hline 1 & $.646^{\mathrm{a}}$ & .418 & .411 & 2.727 \\
\hline
\end{tabular}

a. Predictors: (Constant), Digital marketing (X1)

Based on the test results obtained a determination value of 0.418 means that digital marketing has an influence contribution of 41.8 percent on sales performance.

Table 7

Test Results for the Determination Coefficient Utilization of promotional media on Sales Performance.

Model Summary

\begin{tabular}{lr|r|r|r}
\hline Model & R & \multicolumn{1}{c}{ R Square } & Adjusted R Square & \multicolumn{1}{c}{ Std. Error of the Estimate } \\
\hline 1 & $.657^{\mathrm{a}}$ & .432 & .426 & 2.693 \\
\hline
\end{tabular}

a. Predictors: (Constant), Use of promotional media (X2)

Based on the test results obtained a determination value of 0.432 means that the use of promotional media has an influence contribution of 43.2 percent on sales performance.

Table 8

Test Results of Digital marketing Determination Coefficient and Use of promotional media on Sales Performance.

Model Summary

\begin{tabular}{ll|rrr}
\hline Model & R & R Square & Adjusted R Square & Std. Error of the Estimate \\
\hline 1 & $.724^{\mathrm{a}}$ & .524 & .514 & 2.478 \\
\hline
\end{tabular}

a. Predictors: (Constant), Use of promotional media (X2), Digital marketing (X1) 
Based on the test results obtained a determination value of 0.524 means that digital marketing and the use of promotional media simultaneously have an influence contribution of 52.4 percent to sales performance, while the remaining 47.6 percent are influenced by other factors.

\section{Hypothesis testing}

\section{Partial hypothesis test ( $t$ test)}

Hypothesis testing with $\mathrm{t}$ test is used to find out which partial hypotheses are accepted. The first hypothesis: There is a significant influence between digital marketing on sales performance.

Table 9

Results of Digital Marketing Hypothesis Tests on Sales Performance.

Coefficients $^{\mathbf{a}}$

\begin{tabular}{|c|c|c|c|c|c|}
\hline \multirow[t]{2}{*}{ Model } & \multicolumn{2}{|c|}{$\begin{array}{l}\text { Unstandardized } \\
\text { Coefficients }\end{array}$} & \multirow{2}{*}{$\begin{array}{c}\text { Standardized } \\
\text { Coefficients } \\
\text { Beta } \\
\end{array}$} & \multirow[b]{2}{*}{$\mathrm{t}$} & \multirow[b]{2}{*}{ Sig. } \\
\hline & B & Std. Error & & & \\
\hline (Constant) & 15.906 & 2.842 & & 5.596 & .000 \\
\hline Digital marketing (X1) & .604 & .074 & 646 & 8.208 & .000 \\
\hline
\end{tabular}

a. Dependent Variable: Sales Performance (Y)

Based on the test results in the above table, the value of $t$ count $>t$ table or $(8,208>1,986)$ is obtained, thus the first hypothesis proposed that there is a significant influence between digital marketing on sales performance is accepted.

Table 10

Hypothesis Test Results Utilization of promotional media on Sales Performance.

Coefficients $^{\mathbf{a}}$

\begin{tabular}{|c|c|c|c|c|c|c|}
\hline \multirow{2}{*}{\multicolumn{2}{|c|}{ Model }} & \multicolumn{2}{|c|}{$\begin{array}{l}\text { Unstandardized } \\
\text { Coefficients }\end{array}$} & \multirow{2}{*}{$\begin{array}{c}\text { Standardized } \\
\text { Coefficients } \\
\text { Beta }\end{array}$} & \multirow[b]{2}{*}{$\mathrm{t}$} & \multirow[b]{2}{*}{ Sig. } \\
\hline & & B & Std. Error & & & \\
\hline & (Constant) & 14.634 & 2.909 & & 5.031 & .000 \\
\hline & $\begin{array}{l}\text { Use of promotional } \\
\text { media (X2) }\end{array}$ & .638 & .075 & .657 & 8.457 & .000 \\
\hline
\end{tabular}

a. Dependent Variable: Sales Performance (Y)

Based on the test results in the table above, the value of $t$ count> $t$ table or (8.457> 1.986) is obtained, thus the second hypothesis proposed that there is a significant influence between the use of promotional media on the sales performance is accepted. 
240 Jurnal Ilmiah Ilmu Administrasi Publik: Jurnal Pemikiran dan Penelitian Administrasi Publik Volume 10 Number 1, January - June 2020. Page 233-243

\section{Simultaneous Hypothesis Test (Test F)}

Hypothesis testing with the $\mathrm{F}$ test is used to find out which simultaneous hypotheses are accepted. The third hypothesis There is a significant influence between digital marketing and the use of promotional media on sales performance.

Table 11

Results of Digital Marketing Hypothesis Testing and Utilization of promotional media on Sales Performance.

ANOVA $^{\mathrm{a}}$

\begin{tabular}{ll|r|r|r|r|r}
\hline Model & Sum of Squares & \multicolumn{1}{c}{ df } & Mean Square & F & Sig. \\
\hline \multirow{2}{*}{1} & Regression & 629.498 & 2 & 314.749 & 51.264 & $.000^{\mathrm{b}}$ \\
\cline { 2 - 7 } & Residual & 571.002 & 93 & 6.140 & & \\
\cline { 2 - 7 } & Total & 1200.500 & 95 & & & \\
\hline
\end{tabular}

Based on the test results in the table above, the calculated F value> F table or (51.264> 2,700 ), thus the third hypothesis proposed that there is a significant influence between digital marketing and the use of promotional media on sales performance is accepted.

\section{Discussion}

\section{The effect of digital marketing on sales performance}

Digital marketing has a significant effect on sales performance with a correlation of 0.646 or has a strong relationship with a contribution of 41.8 percent. Hypothesis testing obtained $t$ count $>\mathrm{t}$ table or $(8,208>1,986)$. Thus the first hypothesis proposed that there is a significant effect between digital marketing on sales performance is accepted.

\section{The effect of using media promotion on sales performance}

The use of promotional media has a significant effect on sales performance with a correlation of 0.657 or has a strong relationship with the contribution of influence of 43.2 percent. Hypothesis testing obtained $t$ count> $t$ table or (8.457> 1.986). Thus the second hypothesis is proposed that there is a significant effect between the use of promotional media on sales performance received.

\section{The effect of digital marketing and the use of promotional media on sales performance}

Digital marketing and the use of promotional media have a significant effect on sales performance by obtaining a regression equation $\mathrm{Y}=9,672+0,362 \mathrm{X} 1+0,405 \mathrm{X} 2$, a correlation value of 0,742 or having a strong relationship with a contribution of 52.4 percent while the remaining 47.6 percent is influenced another factor. Hypothesis testing obtained $F$ value $>\mathrm{F}$ table or $(51.264>2,700)$. Thus the third hypothesis proposed that there is a significant effect between digital marketing and the use of promotional media on sales performance is accepted. 


\section{CONCLUSION}

Digital marketing has a significant effect on sales performance with a contribution of 41.8 percent. Hypothesis testing obtained $t$ count $>t$ table or $(8,208>1,986)$. The use of promotional media has a significant effect on sales performance with an influence contribution of 43.2 percent. Hypothesis testing obtained $t$ count> $t$ table or (8.457> 1.986). Digital marketing and the use of promotional media have a significant effect on sales performance with a contribution of 52.4 percent while the remaining 47.6 percent are influenced by other factors. Hypothesis testing obtained by the calculated $\mathrm{F}$ value $>\mathrm{F}$ table or $(51.264>2,700)$.

\section{REFERENCES}

Aras, M., Jasruddin, J., Akib, H., and Syam, H. (2018). Marketing Mix Study at Hero Tailor. IOSR Journal of Business and Management (IOSR-JBM), 20(4), 45-51.

Aras, M., Syam, H., Jasruddin, J., Akib, H., and Haris, H. (2017). The effect of service marketing mix on consumer decision making. International Conference on Education, Science, Art and Technology, 108-112.

Bautista, A. (2020). Strategic planning model to increase the profitability of an HR outsourcing SME through digital transformation. Advances in Intelligent Systems and Computing (Vol. 1018, pp. 856-862).

Creswell, J. W., and Creswell, J. D. (2017). Research design: Qualitative, quantitative, and mixed methods approaches. Sage publications.

Farida, U., Wagiyanto, E., Bustamin, M., and Salam, R. (2017). Analysis of Empowerment Program that was Implemented in Mamuju Regency East Sulawesi Indonesia. 2nd International Conference on Education, Science, and Technology (ICEST 2017).

Foroudi, P. (2017). Digital technology and marketing management capability: achieving growth in SMEs. Qualitative Market Research, 20(2), 230-246.

Gamache, S. (2019). Development of a digital performance assessment model for Quebec manufacturing SMEs. In Procedia Manufacturing (Vol. 38, pp. 1085-1094).

Harisudin, M. (2011). Competitive profile matrix sebagai alat analisis strategi pemasaran produk atau jasa. Jurnal Sepa, 7(2), 80-84.

Hendrawan, A. (2019). Pengaruh marketing digital terhadap kinerja penjualan produk umkm asti gauri di kecamatan bantarsari cilacap. Jurnal Administrasi Dan Kesekretarisan, 4(1), $50-61$.

Jasmani, J., and Sunarsi, D. (2020). The Influence of Product Mix, Promotion Mix and Brand Image on Consumer Purchasing Decisions of Sari Roti Products in South Tangerang. PINISI Discretion Review, 1(1), 165-174.

Keller, K., and Lane, K. (2013). Marketing Management. New Jersey: Prentice Hall. 
242 Jurnal Ilmiah Ilmu Administrasi Publik: Jurnal Pemikiran dan Penelitian Administrasi Publik Volume 10 Number 1, January - June 2020. Page 233-243

Kriechbaumer, F. (2014). SME website implementation factors in the hospitality industry: Groundwork for a digital marketing roadmap. Worldwide Hospitality and Tourism Themes, 6(4), 328-351.

Matopoulos, A. (2012). Digital business ecosystem prototyping for SMEs. Journal of Systems and Information Technology, 14(4), 286-301.

Miersch, P. (2018). Digital learning resource. Learning 4.0 in SMEs. WT Werkstattstechnik, 108(11), 840-844.

Mitroulis, D. (2019). Evaluating digital transformation strategies: A MCDA analysis of Greek tourism SMEs. Proceedings of the European Conference on Innovation and Entrepreneurship, ECIE (Vol. 2, pp. 667-676).

Purwanti, P., Sarwani, S., and Sunarsi, D. (2020). Pengaruh Inovasi Produk Dan Brand Awareness Terhadap Keputusan Pembelian Konsumen Pada PT. Unilever Indonesia. INOVASI, 7(1), 24-31.

Rengifurwarin, Z. A., Akib, H., and Salam, R. (2018). Snapshot of public service quality in the center for integrated business service (CIBS), cooperative micro small and medium enterprises (CMSME), Maluku Province, Indonesia. Journal of Entrepreneurship Education.

Rivera-Trigueros, I. (2019). Digital Marketing andPpresence 2.0. the Case of Andalusian Health SMES. RISTI - Revista Iberica de Sistemas E Tecnologias de Informacao, 2019, 32-44.

Saputra, E., and Rindrasih, E. (2012). Participatory planning and village tourism SMEs: A case study of Bantul Regency, Yogyakarta, Indonesia. Geografia: Malaysian Journal of Society and Space, 8(7), 54-64. 